\title{
Assessment of Salinity Stress Tolerance in Some Barley Genotypes
}

\author{
Sally, E. El-Wakeel ${ }^{1}$, Ashgan, M. Abdel-Azeem ${ }^{1}$, and El-Shimaa E. I. Mostafa ${ }^{2}$ \\ ${ }^{1}$ Barley Research Dep., Field Crops Research Institute, ARC, Egypt \\ ${ }^{2}$ Seed Technology Research Unit (Mansura) Field Corps Research Institute, ARC, Egypt.
}

\begin{abstract}
This study examined seven barley genotypes in two evaluation experiments; the $1^{\text {st }}$ under normal condition at Sakha station while the $2^{\text {nd }}$ under salt stress at the El-Hosinia station, during two growing seasons (2016/2017 and 2017/2018) and made Laboratory experiment at Seed Technology Research Unit in Mansura, Dakahalia Governorate, Field Corps Research Institute, Agricultural Research Center, Egypt. During 2017 season to study the efficacy of barley seed with characters under different salinity levels $\left(0,10,12,14\right.$ and $\left.16 \mathrm{dSm}^{-1}\right)$ using Rashid salt. The randomized complete block design with 3 replications was used for each experiment. Nine traits were recorded, days to heading, days to maturity, plant height $(\mathrm{cm})$, spike length $(\mathrm{cm})$, No. of spikes $\mathrm{m}^{-2}$, No. of grains spike $\mathrm{e}^{-1}$, straw yield $\left(\mathrm{t} . \mathrm{ha}^{-1}\right)$, grain yield $\left(\mathrm{t} . \mathrm{ha}^{-1}\right)$ and harvest index (HI). Other five traits were recorded in Laboratory experiment; shoot length, root length, seedling dry weight $(\mathrm{g}), \mathrm{K}^{+}$content and $\mathrm{N}^{+}$a content. Besides, eight stress tolerance indices were evaluated (TOL, MP, STI, GMP, Yr, DSI, YSI, YI). The combined analysis of variance for years, locations, genotypes, and interaction was significant and highly significant for all studied traits; Results revealed that Line 4, Line 2 and linel gave the highest values under two conditions in both seasons for grain yield $\left(\mathrm{t} . \mathrm{ha}^{-1}\right)$. For indices of salinity tolerance, the Productivity MP Values obtained by Line4; Line2; Giza123 and Line1. Moreover, these four tolerant genotypes recorded high values for GMP, STI, YSI, and YI. Significant differences were observed between salinity levels, whereas level $\left(10 \mathrm{dSm}^{-1}\right)$ was lowest harmful in connection. Compared with other Salinity levels. On the other hand, the highest harmful of parameters was obtained by Salinity level $\left(16 \mathrm{dSm}^{-1}\right)$.
\end{abstract}

Keywords: Barley, salt stress, grain yield, indices of salinity tolerance.

\section{INTRODUCTION}

Barley(Hordeum vulgare L.) is an important crop used as feed, malt, and food (Katerji et al., 2006). Salt tolerance is needed for crops grown in areas at risk of salinization. New genetic materials of salt tolerance and more efficient techniques for genotypes screening and identification are needed (Rana et al., 2002); germination and seedling growth in saline environments are widely-used screening criteria to identify salt- tolerant genotypes (Ashraf et al., 2015; Ashraf, 1990; Taghipour and Salehi, 2008). High plant population is only possible if seed germination is satisfactory under saline conditions (Nasser et al., 2001). During germination and early stages of development, crops are particularly sensitive to high salinity levels, whereas, crops at an advanced growth stage are more vigorous. This is due to that germination and early seedling taking place in surface soil, where, there is high salt accumulation due to evapotranspiration (El Goumi et al., 2014).

Salinity is among the most serious dangers threatening environment and agriculture in many parts of the world, and it influences the performance of crops and yield in arid and semi-arid regions. Increase in the concentration of salts in soil solution or irrigation water has been considered one of the oldest agricultural and environmental problems. Presence of high rate of salts in the soil or irrigation water confronts the plant with salinity stress. Therefore, the level of salt tolerance of different barley genotypes must be evaluated at different growth stages. Also an appropriate statistical method to simultaneously analyzes multiple agronomic parameters, facilitate ranking genotypes for salt tolerance. Therefore, the main objective of this study was to identify promising barley genotypes that can produce high yield and are more tolerant to salinity stress conditions.

\section{MATERIALS AND METHODS}

\section{Field experiments:}

Seven six-row barley genotypes were used in this study, including two local varieties (Giza 123 and Giza 132) and five promising Egyptian lines. The list of the seven genotypes and pedigree were presented in Table 1. The seven barley genotypes were evaluated at two different field environments; normal conditions and salt stress. Normal condition was conducted at Sakha Agricultural Research Station. While, salt-stress experiment was conducted at the El-Hosinia Agricultural Research Station (salt-affected soil). Normal experiment was irrigated three times. Kernels were hand drilled at the recommended seeding rate for barley irrigated land of Egypt $\left(50 \mathrm{~kg} \mathrm{fad}^{-1}\right)$. Each genotype was sown in 15 rows of $3.5 \mathrm{~m}$ long and $20 \mathrm{~cm}$ apart rows (plot area $10.5 \mathrm{~m}^{2}$ ). This experiment was laid out in an RCBD with three replications. Sowing was done in the first of December in two seasons, (2016/2017 and 2017/2018).

Soil samples were randomly taken from the experimental area at a depth of 0 to $30 \mathrm{~cm}$ from soil 
surface before barley sowing. The soil properties were shown in Table2.

Collected data were used for diving the following parameters;

1- Stress tolerance (TOL) =YP-YS (Fernandez, 1992).

2- Mean productivity (MP) $=\frac{Y s+Y p}{2}$

(Hossain et al., 1990).

3- Yield reduction ratio $(\mathrm{Yr})=1-\frac{\mathrm{Ys}}{Y \mathrm{p}}$

(Golestani and Assad,1998).

4- Drought susceptibility index (DSI) = (1Ys/Yp)/D (Fischer and Maurer, 1978).

5- Geometrical mean productivity $(G M P)=(Y p \times Y s)^{0.5}($ Fernandez, 1992).

6- Stress tolerance index $(\mathrm{STI})=\frac{\mathrm{Yp}+\mathrm{Ys}}{\overline{\mathrm{Y}} p^{2}}$

(Fernandez, 1992).

7- Yield stability index $(Y S I)=\frac{Y s}{Y p}$

(Bouslama and Schapaugh, 1984).

8- Yield index (YI) $=\frac{Y s}{\bar{Y}_{s}} \quad$ (Gavuzzi et al., 1997).

Where as; $\mathrm{Ys}=$ mean yield under stress, $\mathrm{Yp}=$ mean yield under normal condition, and $\mathrm{D}=$ environmental stress intensity $=1$-(mean yield of all genotypes under stress/mean yield of all genotypes under normal condition). Lower stress susceptibility index than unity (DSI $<1$ ) is synonymous to highstress tolerance, while high- stress susceptibility index (DSI $>1$ ) means higher stress sensitivity.

Where Ys is the yield of genotype under stress, $Y p$ is the yield of genotype under normal condition, $\bar{Y}_{S}$ and $\bar{Y} p$ are the mean yields of all genotypes under stress and non-stress conditions, respectively.

\section{Laboratory experiment:}

Laboratory experiments were conducted at the Seed Technology Research Unit, Field Corps Research Institute, Agricultural Research Center, Mansura, Dakahalia Governorate, Egypt, two times in 2017 season, to study the response of barley seed under different salinity levels $(0,10,12,14$ and 16 $\mathrm{dSm}^{-1}$ ) using Rashid salt(sodium chloride). Barley cultivars were Sakha 123, Sakha 132 and five lines 1,2,3,4 and 5 provided by Barley Research Station, Field Crops Research Institute, Agricultural Research Center, Egypt.

from each treatment 375 seeds were placed in sterilized Petri dishes $(150 \times 15 \mathrm{~mm})$ containing 3 layers of Whatman No.1 filter paper that had been autoclaved and moistened with $10 \mathrm{ml}$ of salinity solutions $(0,10,12,14$ and $16 \mathrm{dS} / \mathrm{m})$ and incubated in the growth chamber at $15 \pm 2{ }^{\circ} \mathrm{C}$ and the following characters were recorded:

Table 1: Name and pedigree of the seven studied barley genotypes used in this study.

\begin{tabular}{ll}
\hline Genotype & \multicolumn{1}{c}{ Pedigree } \\
\hline GIZA 123 & Giza 117/FAO 86 \\
\hline GIZA132 & Rihane-05//As46/Aths*2" Aths/Lignee686 \\
\hline Line-1 & Lignee527/Aths//Lignee527/NK1272/3/Arar/Rhn-03 \\
\hline Line-2 & Giza126/3/Lignee527/NK1272//Alanda/6/Lignee527// \\
& Bahtim/DL71/3/Api/CM67//Mzq/5/Alanda-01/4/ \\
& WI2291/3/Api/CM67//L2966-69 \\
\hline Line-3 & ACSAD1182/4/Arr/ESP//Alger/Ceres362-1-1/3/WI/6/Lignee527//Bahtim/ \\
& DL71/3/Api/CM67//Mzq/5/Ager//Api//CM67/3/Cel/WI2269// Ore/4/Hamra-01 \\
\hline Line-4 & Alanda/Harma//Alanda-01/3/ACSAD1612 \\
\hline Line-5 & Alanda/Hamra//Alanda-01//Giza 2000 \\
\hline
\end{tabular}

Table 2: Some soil mechanical and chemical analysis before sowing at 0-30 cm depth for Sakha and ElHosinia Research stations during 2016/2017 and 2017/2018 seasons.

\begin{tabular}{lcccc}
\hline \multirow{2}{*}{ Soil Properties } & \multicolumn{2}{c}{ Sakha } & \multicolumn{2}{c}{ El-Hosinia } \\
\cline { 2 - 5 } & $\mathbf{2 0 1 6 / 2 0 1 7}$ & $\mathbf{2 0 1 7 / 2 0 1 8}$ & $\mathbf{2 0 1 6 / 2 0 1 7}$ & $\mathbf{2 0 1 7 / 2 0 1 8}$ \\
\hline Mechanical analysis & 13.2 & 16.2 & 17.9 & 10.5 \\
Sand & 37.5 & 36.3 & 35.3 & 39.6 \\
Silt & 49.3 & 47.5 & 46.8 & 49.9 \\
Clay & \multicolumn{3}{c}{ Chemical analysis } \\
\hline pH & 8.1 & 8.2 & 8.3 & 8.5 \\
EC dSm & 2.2 & 2.1 & 15.7 & 12.3 \\
ESP & 7.3 & 7.6 & 13.2 & 13.9 \\
\hline
\end{tabular}


Shoot and root length $(\mathrm{cm})$ : Measured as the mean of ten normal seedlings 14 days after planting

Seedling dry weight $(\mathrm{g})$ : Ten normal seedlings were dried in a hot-air oven at $85^{\circ} \mathrm{C}$ for $12 \mathrm{~h}$ to obtain the seedling dry weight $(\mathrm{g})$ according to Krishnasamy and Seshu (1990).

$\mathrm{K}^{+}$and $\mathrm{Na}+(\mathrm{mg} / \mathrm{dry}$ weight) were determined according to (Jackson, 1973). obtained data were subjected to statistical analysis of variance (ANOVA) using the completely randomized design, as described by Gomez and Gomez (1984).

\section{RESULTS AND DISCUSSION}

\section{1- Field experiments}

\section{Analysis of variance:}

Mean squares for the studied characters of the seven barley genotypes under both non- stress and stress environments in the two seasons were presented in Table (3). The results indicated that the differences among years, environments and genotypes were highly significant for all studied traits except for the mean squares of No. of grains spike $^{-1}$ and grain yield were non-significant for years and No. of grains spike ${ }^{-1}$ for environments. Also, the mean square of interaction between the years $\mathrm{x}$ locations were highly significant for days to maturity, No. of grains spike $e^{-1}$, number of spikes $\mathrm{m}^{-}$ ${ }^{2}$, grain yield and harvest index $(\mathrm{HI})$, genotypes $\mathrm{x}$ environments were significant and highly significant for all studied traits except for days to heading, No. of grains spike $^{-1}$ and harvest index(HI). While genotypes $\mathrm{x}$ years $\mathrm{x}$ environments found to be highly significant for plant height, biological yield and harvest index (HI). While, significant for spike length, No. of grains spike ${ }^{-1}$ and grain yield. These results indicated that, the studied genotypes responded differently to the environmental conditions suggesting the importance of the assessment of genotypes under different environments to identify the best genotypes that more adapted for a particular environment.

The effect of year, environment and genotype on the studied characteristics for the two seasons were presented in Table (4).

\section{Effect of Season}

The second season had higher mean values of all studied characters compared to the first season except for days to heading, days to maturity, plant height and no. of grains .spikes ${ }^{-1}$.

\section{Effect of environment}

The normal condition(Sakha)showed the highest values for all characters compared to the salt stress condition (El-Hosinia).

\section{Effect of genotypes}

Regarding the genotypes means across seasons and environments, line 1 had the earliest in heading date, while Giza 132, and Line 4 were the latest. Giza123, Line1 and Line5 were the earliest in maturity, while Line4 showed the reverse trend for the same characters. Line2 possessed the highest mean values for plant height and grain yield.

Table 3: The combined analyses of variance over years (Y), locations (L) and genotypes (G) for all studied traits.

\begin{tabular}{lcccccc}
\hline S.O.V & df & Days to heading & Days to maturity & Plant height & Spike length & $\begin{array}{c}\text { No. of grains } \\
\text { spike- }\end{array}$ \\
\hline Years (Y) & 1 & $2663.44^{* *}$ & $1029^{* *}$ & $3562.01^{* *}$ & $1.19^{*}$ & $2.68 \mathrm{~ns}$ \\
\hline Location (L) & 1 & $398.68^{* *}$ & $685.71^{* *}$ & $11691.44^{* *}$ & $46.21^{* *}$ & $223.44 \mathrm{~ns}$ \\
\hline Y x L & 1 & $1.44 \mathrm{~ns}$ & $128.76^{* *}$ & $152.01^{*}$ & $0.16 \mathrm{~ns}$ & $750.01^{* *}$ \\
\hline Genotypes (G) & 6 & $34.93^{* *}$ & $44.57^{* *}$ & $255.8^{* *}$ & $10.11^{* *}$ & $271.27^{* *}$ \\
\hline G x Y & 6 & $28.83^{* *}$ & $7.69^{* *}$ & $8.65 \mathrm{~ns}$ & $0.91^{*}$ & $48.46 \mathrm{~ns}$ \\
\hline G x E & 6 & $1.76 \mathrm{~ns}$ & $4.41^{*}$ & $39.8^{* *}$ & $0.8^{*}$ & $52.08 \mathrm{~ns}$ \\
\hline Gx Y x E & 6 & $4.91^{\mathrm{C}}$ & $3.62^{\mathrm{n} . \mathrm{s}}$ & $50.65^{* *}$ & $0.79^{*}$ & $112.98^{*}$ \\
\hline Error & 48 & 2.55 & 1.71 & 11.16 & 0.35 & 47.63 \\
\hline
\end{tabular}

Table 3: Cont.

\begin{tabular}{llcccc}
\hline S.O.V & df & Number of spikes $\mathbf{~ m}^{-2}$ & grain yield & straw yield & HI \% \\
\hline ears (Y) & 1 & $170730.583^{* *}$ & $1.36^{* *}$ & $0.17 \mathrm{~ns}$ & $18.77^{* *}$ \\
\hline Location (L) & 1 & $102270.96^{* *}$ & $50.04^{* *}$ & $150.2^{* *}$ & $65.31^{* *}$ \\
\hline Y x L & 1 & $15228.11^{* *}$ & $0.04 \mathrm{~ns}$ & $10.9^{* *}$ & $31.76^{* *}$ \\
\hline Genotypes (G) & 6 & $3204.1^{* *}$ & $1.10^{* *}$ & $3.84^{* *}$ & $17.96^{* *}$ \\
\hline G x Y & 6 & $3736.19^{* *}$ & $0.49^{* *}$ & $1.19^{* *}$ & $18.28^{* *}$ \\
\hline G x E & 6 & $1641.38^{* *}$ & $0.17^{* *}$ & $0.46^{*}$ & $5.18^{*}$ \\
\hline G x Y x E & 6 & $296.75^{\text {n.s }}$ & $0.07^{\text {n.s }}$ & $0.71^{* *}$ & $4.60^{*}$ \\
\hline Error & 48 & 198.13 & 0.05 & 0.20 & 1.68 \\
\hline * and ** indicate significance at 0.05 and 0.01 levels, respectively. & &
\end{tabular}


Table 4: Means of the seven genotypes over years and environments.

\begin{tabular}{|c|c|c|c|c|c|c|c|c|c|}
\hline Item & $\begin{array}{l}\text { days to } \\
\text { heading }\end{array}$ & $\begin{array}{l}\text { days to } \\
\text { maturity }\end{array}$ & $\begin{array}{l}\text { plant } \\
\text { height }\end{array}$ & $\begin{array}{l}\text { spike } \\
\text { length }\end{array}$ & $\begin{array}{c}\text { no. of } \\
\text { grains } \\
\text { spike }^{-1}\end{array}$ & $\begin{array}{l}\text { Number of } \\
\text { spikes } \mathbf{m}^{-2}\end{array}$ & $\begin{array}{r}\text { straw } \\
\text { yield }\end{array}$ & $\begin{array}{l}\text { grain } \\
\text { yield }\end{array}$ & HI\% \\
\hline \multicolumn{10}{|c|}{ Years } \\
\hline First Year & 89.5 & 128.2 & 119.4 & 7.5 & 59.9 & 264.4 & 11.98 & 4.94 & 29.1 \\
\hline Second year & 78.2 & 121.2 & 106.4 & 7.7 & 59.6 & 354.6 & 12.07 & 5.19 & 30.0 \\
\hline L.S.D 0.05 & 0.70 & 0.57 & 1.46 & 0.26 & 3.01 & 6.14 & 0.472 & 0.240 & 1.389 \\
\hline \multicolumn{10}{|c|}{ Locations } \\
\hline Sakha & 86.0 & 127.6 & 124.7 & 8.3 & 61.4 & 344.4 & 13.36 & 5.84 & 30.4 \\
\hline El- hosinia & 81.7 & 121.9 & 101.1 & 6.9 & 58.1 & 274.6 & 1.069 & 4.30 & 28.7 \\
\hline L.S.D 0.05 & 0.70 & 0.57 & 1.46 & 0.26 & 3.01 & 6.14 & 0.472 & 0.240 & 1.389 \\
\hline \multicolumn{10}{|c|}{ Genotypes } \\
\hline Giza123 & 84.2 & 122.9 & 113.8 & 7.8 & 60.1 & 291.3 & 11.94 & 5.15 & 30.1 \\
\hline Giza132 & 85.5 & 125.7 & 117.1 & 7.1 & 51.6 & 305.0 & 10.94 & 4.86 & 30.6 \\
\hline Line 1 & 81.1 & 123.0 & 108.8 & 7.2 & 56.0 & 302.1 & 12.08 & 4.96 & 29.1 \\
\hline Line 2 & 82.8 & 126.8 & 120.8 & 8.4 & 58.9 & 323.5 & 12.74 & 5.34 & 29.5 \\
\hline Line 3 & 83.6 & 124.2 & 108.9 & 6.2 & 65.3 & 334.4 & 11.82 & 5.01 & 29.6 \\
\hline Line 4 & 86.3 & 127.5 & 110.8 & 9.0 & 62.5 & 318.1 & 12.34 & 5.53 & 30.9 \\
\hline Line 5 & 83.5 & 123.1 & 109.8 & 7.4 & 63.7 & 292.0 & 12.30 & 4.62 & 27.2 \\
\hline L.S.D ${ }_{0.05}$ & 1.306 & 1.069 & 2.733 & 0.482 & 5.647 & 11.516 & 0.361 & 0.184 & 1.061 \\
\hline
\end{tabular}

While, Line4 was the tallest in spike length Also, Line3, Line4, and Line5 recorded the highest mean values for no. of grains . spikes $^{-1}$, Moreover, Line3 and Line2 scored the highest mean values for the number of spikes m-2. Also, Line4 had the highest mean values for biological yield and harvest index ( $\mathrm{HI} \%)$.

Overall mean values for days to heading for different genotypes ranged from (89 days) for Line 2 to (96.67 days) for G132 under normal condition. On the other hand, line 1 was the earliest genotype (83 days) under stress condition. While G 132 was the latest genotype(92days)under the same condition in the first season. In the second season values ranged from (77.67 days) for G132 to (83 days) for line4 under normal condition. While ranged from (73.3 days) for line1 to(78.0 days) for line5 under stress condition Table(5). The average of days to maturity, G123 was the earliest genotype (127 days) under normal condition. Also, line 1 was the earliest genotype conditions (127 and 123.3 days respectively) under both in the first season. While line 5 was the earliest genotype (121.0 and 115.7 days, respectively) under normal and stress conditions in the second season. (Table 5).

Table 5: Means of days to heading and days to maturity for the seven studied genotypes under normal (N) and saline soil (S) during 2016/2017 and 2017/2018 seasons.

\begin{tabular}{|c|c|c|c|c|c|c|c|c|}
\hline \multirow[b]{3}{*}{ Genotypes } & \multicolumn{4}{|c|}{ Days to heading (day) } & \multicolumn{4}{|c|}{ Days to maturity (day) } \\
\hline & \multicolumn{2}{|c|}{$2016 / 2017$} & \multicolumn{2}{|c|}{$2017 / 2018$} & \multicolumn{2}{|c|}{$2016 / 2017$} & \multicolumn{2}{|c|}{$2017 / 2018$} \\
\hline & $\mathbf{N}^{*}$ & $\mathbf{S}$ & $\mathbf{N}$ & $\mathbf{S}$ & $\mathbf{N}$ & $\mathbf{S}$ & $\mathbf{N}$ & $\mathbf{S}$ \\
\hline G123 & 91.67 & 87.67 & 80.67 & 76.67 & 127.00 & 124.33 & 123.33 & 117.00 \\
\hline G132 & 96.67 & 92.33 & 77.67 & 75.33 & 131.67 & 128.00 & 127.00 & 116.00 \\
\hline Line-1 & 89.67 & 83.00 & 78.33 & 73.33 & 127.00 & 123.33 & 124.00 & 117.67 \\
\hline Line-2 & 89.00 & 87.00 & 80.67 & 74.67 & 132.00 & 129.33 & 128.33 & 117.67 \\
\hline Line-3 & 89.67 & 86.33 & 82.00 & 76.33 & 129.00 & 126.00 & 125.00 & 116.67 \\
\hline Line-4 & 94.00 & 91.00 & 83.00 & 77.00 & 133.00 & 129.00 & 128.67 & 119.33 \\
\hline Line-5 & 90.00 & 84.67 & 81.33 & 78.00 & 129.33 & 126.33 & 121.00 & 115.67 \\
\hline $\operatorname{LSD}_{0.05}(\mathrm{G})$ & 3.28 & 1.80 & 1.35 & 2.40 & 2.57 & 2.13 & 1.50 & 1.05 \\
\hline $\operatorname{LSD}_{0.05}(\mathrm{G} \times \mathrm{L})$ & \multicolumn{2}{|c|}{-} & \multicolumn{2}{|c|}{-} & \multicolumn{2}{|c|}{1.51} & \multicolumn{2}{|c|}{1.51} \\
\hline $\mathrm{LSD}_{0.05}(\mathrm{G} \times \mathrm{L} \times \mathrm{Y})$ & \multicolumn{4}{|c|}{-} & \multicolumn{4}{|c|}{-} \\
\hline
\end{tabular}


Concerning plant height, data recorded that line 2 was the tallest genotype under both conditions $(140,115.7 \mathrm{~cm})$,while line1 was the shortest genotype under normal condition $(126 \mathrm{~cm})$ and also, line 5 was the shortest genotype under stress condition $(100 \mathrm{~cm})$ in the first season. In the second season, line 2 was the tallest genotype while line3 was the shortest genotype $(122,110 \mathrm{~cm})$ respectively under normal condition. On contrast G132 (106 cm) was the tallest genotype and line $1(88.3 \mathrm{~cm})$ was the shortest genotype under stress condition (Table 6). The reduction in plant height could be attributed to lower crop growth rate and the decrease in relative water content. These results are in harmony with those of Nabipour et al., (2002), Bayoumi (2004), Mohamed (2004), Farhat (2005), Bagheri and Abad (2007), Samarah et al.,(2009) and Vaezi et al., (2010).

For spike length, means of the seven barley genotypes showed that Line 2 gave the highest values under normal condition $(9.67 \mathrm{~cm})$ in the first season and similar trend under stress condition (7.83 $\mathrm{cm})$ in the second season. Also, line 4 gave the tallest spike length $(9.67,8.33,10.33$ and $7.80 \mathrm{~cm})$ respectively, under all conditions in both seasons (Table 6).

Regarding the number of spikes $\mathrm{m}^{-2}$, data in Table (7) showed that line 4 gave the highest values (334.67and412.33 spikes), respectively under normal condition in both seasons. Also, line 1 (247.67 spikes) under stress condition in the first season and line 3(382.67 spikes) under the same condition in the second season. Whereas line $5(280.67$ and 174.00 spikes $)$ was the lowest genotype under both conditions in the first season and also, Giza 123 (324.67 and298.67 spikes) in the second season, The genotypes under normal condition recorded the highest number of spikes $\mathrm{m}^{-2}$ and The saline stress treatments decreased spikes number in both growing seasons. Such response may be attributed to a lack of water absorbed and reduction in photosynthetic efficiency under insufficient normal condition. Moreover, the reduction in assimilates translocated to new developing tillers might owe much the death of the new tillers and depressed the number of spikes primordial. These results are confirmed by Abd ElWahab (2002), Bayoumi (2004), Mohamed (2004), Farhat (2005), Mahmoud (2006), Bagheri and Abad (2007), Samarah et al., (2009) and Vaezi et al., (2010).

Concerning the response of grains number spike $^{-1}$, the differences among genotypes were significant in both growing seasons, indicating overall differences between growth conditions. Line 3 (74.33 and 64.67 grains) under both conditions in the first season, line 4 (68.00 grains) under normal condition and Giza 123(69.67grains) under stress condition in the second season, produced the highest mean number of grains spike $^{-1}$ (Table 7).on the other hand, Giza 132 revealed lowest number of grains spike ${ }^{-1}$ at the two conditions $(52.67,46.33$ grains) in the first season and under normal condition (50.33 grains) in the second season. Also, line 4(53.67 grains) was the lowest value under stress condition in the second season in the same traits. The number of grains $\operatorname{spike}^{-1}$ (fertility) depends on water availability during the early vegetative phase and shooting stages. If water deficit occurs after the flowering stage, it induces a decrease of grain weight and thus its yield The results are in agreement with obtained by Mohamed (2004), Farhat (2005), Bagheri and Abad (2007), Samarah et al., (2009) and Vaezi et al., (2010)

Table 6: Means of plant height $(\mathrm{cm})$ and spike length $(\mathrm{cm})$ for the seven studied genotypes under normal (N) and saline soil (S) during 2016/2017 and 2017/2018 seasons.

\begin{tabular}{|c|c|c|c|c|c|c|c|c|}
\hline \multirow[b]{3}{*}{ Genotypes } & \multicolumn{4}{|c|}{ plant height (cm) } & \multicolumn{4}{|c|}{ spike length (cm) } \\
\hline & \multicolumn{2}{|c|}{$2016 / 2017$} & \multicolumn{2}{|c|}{$2017 / 2018$} & \multicolumn{2}{|c|}{$2016 / 2017$} & \multicolumn{2}{|c|}{$2017 / 2018$} \\
\hline & $\mathbf{N}$ & $\mathbf{S}$ & $\mathbf{N}$ & $\mathbf{S}$ & $\mathbf{N}$ & $\mathbf{S}$ & $\mathbf{N}$ & $\mathbf{S}$ \\
\hline G123 & 135.67 & 105.00 & 121.33 & 93.33 & 9.00 & 7.00 & 7.93 & 7.17 \\
\hline G132 & 135.00 & 109.33 & 118.00 & 106.00 & 7.67 & 6.83 & 7.70 & 6.27 \\
\hline Line-1 & 126.00 & 106.67 & 114.33 & 88.33 & 7.83 & 6.67 & 7.33 & 6.90 \\
\hline Line-2 & 140.00 & 115.67 & 122.00 & 105.67 & 9.67 & 6.67 & 9.42 & 7.83 \\
\hline Line-3 & 130.00 & 103.00 & 110.67 & 92.00 & 6.33 & 5.00 & 7.80 & 5.75 \\
\hline Line-4 & 129.33 & 104.00 & 119.33 & 90.67 & 9.67 & 8.33 & 10.33 & 7.80 \\
\hline Line-5 & 131.67 & 100.00 & 112.00 & 95.33 & 7.67 & 6.33 & 8.37 & 7.40 \\
\hline $\operatorname{LSD}_{0.05}(\mathrm{G})$ & 1.22 & 5.43 & 3.98 & 6.90 & 1.06 & 1.01 & 0.65 & 0.61 \\
\hline $\operatorname{LSD}_{0.05}(\mathrm{G} \times \mathrm{L})$ & \multicolumn{2}{|c|}{3.86} & \multicolumn{2}{|c|}{3.86} & \multicolumn{2}{|c|}{0.68} & \multicolumn{2}{|c|}{0.68} \\
\hline $\operatorname{LSD}_{0.05}(\mathrm{G} \times \mathrm{L} \times \mathrm{Y})$ & \multicolumn{4}{|c|}{5.45} & \multicolumn{4}{|c|}{0.96} \\
\hline
\end{tabular}


Table 7: Means of no. of spikes $\mathrm{m}^{-2}$ and no. of grains spike $\mathrm{e}^{-1}$ for the seven studied genotypes under normal $(\mathrm{N})$ and saline soil (S) during $2016 / 2017$ and 2017/2018 seasons.

\begin{tabular}{|c|c|c|c|c|c|c|c|c|}
\hline \multirow[b]{3}{*}{ Genotypes } & \multicolumn{4}{|c|}{ no. of spikes $\mathrm{m}^{-2}$} & \multicolumn{4}{|c|}{ no. of grains spike ${ }^{-1}$} \\
\hline & \multicolumn{2}{|c|}{$2016 / 2017$} & \multicolumn{2}{|c|}{$2017 / 2018$} & \multicolumn{2}{|c|}{$2016 / 2017$} & \multicolumn{2}{|c|}{$2017 / 2018$} \\
\hline & $\mathbf{N}$ & $\mathbf{S}$ & $\mathbf{N}$ & $\mathbf{S}$ & $\mathbf{N}$ & $\mathbf{S}$ & $\mathbf{N}$ & $\mathbf{S}$ \\
\hline G123 & 300.0 & 242.0 & 324.7 & 298.7 & 63.3 & 54.0 & 53.3 & 69.7 \\
\hline G132 & 328.0 & 220.7 & 355.3 & 316.0 & 52.7 & 46.3 & 50.3 & 57.0 \\
\hline Line-1 & 307.3 & 247.7 & 345.3 & 308.0 & 61.3 & 52.0 & 55.3 & 55.3 \\
\hline Line-2 & 322.7 & 213.3 & 407.3 & 350.7 & 62.3 & 54.0 & 61.0 & 58.3 \\
\hline Line-3 & 316.0 & 229.3 & 409.7 & 382.7 & 74.3 & 64.7 & 58.7 & 63.7 \\
\hline Line-4 & 334.7 & 185.3 & 412.3 & 340.0 & 66.3 & 62.0 & 68.0 & 53.7 \\
\hline Line-5 & 280.7 & 174.0 & 377.3 & 336.0 & 71.3 & 54.0 & 60.7 & 68.7 \\
\hline $\operatorname{LSD}_{0.05}(\mathrm{G})$ & 18.9 & 16.7 & 9.7 & 30.8 & 3.6 & 6.9 & 2.7 & 18.3 \\
\hline $\operatorname{LSD}_{0.05}(\mathrm{G} \times \mathrm{L})$ & \multicolumn{2}{|c|}{16.3} & \multicolumn{2}{|c|}{16.3} & \multicolumn{2}{|c|}{-} & \multicolumn{2}{|c|}{-} \\
\hline $\operatorname{LSD}_{0.05}(G \times L \times Y)$ & \multicolumn{4}{|c|}{-} & \multicolumn{4}{|c|}{11.3} \\
\hline
\end{tabular}

$\mathrm{N}$; normal $\quad \mathrm{S}$; Stressed (Saline-soil).

The scored data in Table (8) showed that the genotypes exhibited significant differences in grain yield $\left(\mathrm{t} . \mathrm{ha}^{-1}\right)$ at the two seasons. Line 4 gave the highest values under normal conditions in both seasons and stress condition in the second season $\left(6.05,6.73\right.$ and $\left.5.04 \mathrm{t} . \mathrm{ha}^{-1}\right)$ respectively. in addition to line1 was the highest mean under stress condition in the first season $\left(4.59 \mathrm{t}\right.$. $\left.\mathrm{ha}^{-1}\right)$. Whereas, line 5 scored the lowest mean values under all conditions in both growing seasons. Results in Table (8) show that genotypes were highly significant differences in straw yield. Line 2 under stress condition (11.70, $10.51 \mathrm{t}$. ha $\mathrm{h}^{-1}$ ) in both seasons, under normal condition $\left(15.23 \mathrm{t}\right.$. ha $\left.{ }^{-1}\right)$ in the second season and Line 4 under normal condition $\left(13.86 \mathrm{t}^{\mathrm{h}} \mathrm{ha}^{-1}\right)$ in the first season gave the highest mean values, respectively. While Giza 132 had bad performance under all conditions at the two seasons.

For harvest index (HI) mean of the genotypes, G132 and Line3 achieved the highest mean performance under normal conditions in the first season. In addition to line 1 under stress condition in the same season. Also, line4 had good performance under normal and stress conditions in the second season. (Table 9).

The quantitative indices of salinity tolerance:

Yield potential (YP), yield stress (YS) and eight salinity tolerant indices such as Tolerance index (TOL), Mean Productivity(MP), Yield reduction ratio(YR), Drought Susceptibility Index (DSI), Geometric Mean Productivity (GMP), Stress Tolerance Index (STI), Yield Stability Index (YSI), Yield Index (YI) were calculated for each genotype (Tables 13,14), overall the two seasons; 2016/2017 and 2017/2018.

Concerning GYP and GYS, there was one genotype gave desired values in both seasons (Table 10) Line $4\left(6.39,4.67\right.$ t. ha $\left.^{-1}\right)$. With the highest general mean

Productivity MP Values obtained by Line4 (5.53 t. ha $\left.{ }^{-1}\right)$; Line2 (5.34 t. ha $\left.{ }^{-1}\right)$. Moreover, these two tolerant genotypes recorded high values for GMP, STI, and YI. The values for GMP of the two genotypes were 5.46 and $5.28 \mathrm{t}$. ha ${ }^{-1}$, respectively. Desired values for STI were found in Line4 (0.48) and Line2 (0.47) in both seasons.

Table 8: Means of grain yield ( $t$. $\left.\mathrm{ha}^{-1}\right)$ and biological yield $\left(\mathrm{t} . \mathrm{ha}^{-1}\right)$ for the seven studied genotypes under normal (N) and saline soil (S) during 2016/2017 and 2017/2018 seasons.

\begin{tabular}{|c|c|c|c|c|c|c|c|c|}
\hline \multirow[b]{3}{*}{ Genotypes } & \multicolumn{4}{|c|}{ grain yield (t. ha $\left.{ }^{-1}\right)$} & \multicolumn{4}{|c|}{ Straw yield (t. ha $\left.{ }^{-1}\right)$} \\
\hline & \multicolumn{2}{|c|}{$2016 / 2017$} & \multicolumn{2}{|c|}{$2017 / 2018$} & \multicolumn{2}{|c|}{$2016 / 2017$} & \multicolumn{2}{|c|}{$2017 / 2018$} \\
\hline & $\mathbf{N}$ & $\mathbf{S}$ & $\mathbf{N}$ & $\mathbf{S}$ & $\mathbf{N}$ & $\mathbf{S}$ & $\mathbf{N}$ & $\mathbf{S}$ \\
\hline G123 & 5.94 & 4.44 & 5.87 & 4.34 & 12.32 & 10.70 & 14.24 & 10.52 \\
\hline G132 & 5.80 & 3.89 & 5.68 & 4.08 & 11.77 & 9.83 & 12.58 & 9.57 \\
\hline Line-1 & 5.31 & 4.59 & 5.66 & 4.29 & 13.52 & 10.83 & 13.29 & 10.67 \\
\hline Line-2 & 5.59 & 4.23 & 6.62 & 4.90 & 13.52 & 11.70 & 15.23 & 10.51 \\
\hline Line-3 & 5.94 & 4.24 & 5.73 & 4.13 & 12.06 & 10.82 & 13.71 & 10.68 \\
\hline Line-4 & 6.05 & 4.30 & 6.73 & 5.04 & 13.86 & 11.58 & 13.90 & 10.02 \\
\hline Line-5 & 5.20 & 3.64 & 5.63 & 4.02 & 13.63 & 11.54 & 13.40 & 10.62 \\
\hline $\operatorname{LSD}_{0.05}(\mathrm{G})$ & 0.46 & 0.45 & 0.25 & 0.23 & 0.18 & 0.12 & 0.12 & 0.12 \\
\hline $\operatorname{LSD}_{0.05}(\mathrm{G} \times \mathrm{L})$ & \multicolumn{2}{|c|}{0.260} & \multicolumn{2}{|c|}{0.260} & \multicolumn{2}{|c|}{0.510} & \multicolumn{2}{|c|}{0.510} \\
\hline $\operatorname{LSD}_{0.05}(\mathrm{G} \times \mathrm{L} \times \mathrm{Y})$ & \multicolumn{4}{|c|}{0.367} & \multicolumn{4}{|c|}{0.722} \\
\hline
\end{tabular}


Table 9: Means of harvest index (HI) for the seven studied genotypes under normal (N) and saline soil (S) during 2016/2017 and 2017/2018 seasons.

\begin{tabular}{|c|c|c|c|c|}
\hline \multirow[b]{3}{*}{ Genotypes } & \multicolumn{4}{|c|}{ harvest index (HI) } \\
\hline & \multicolumn{2}{|c|}{$2016 / 2017$} & \multicolumn{2}{|c|}{$2017 / 2018$} \\
\hline & $\mathrm{N}$ & $\mathrm{S}$ & $\mathrm{N}$ & $\mathrm{S}$ \\
\hline G123 & 32.6 & 29.4 & 29.2 & 29.2 \\
\hline G132 & 33.0 & 28.3 & 31.1 & 29.9 \\
\hline Line-1 & 28.2 & 29.8 & 29.8 & 28.7 \\
\hline Line-2 & 29.3 & 26.5 & 30.3 & 31.8 \\
\hline Line-3 & 33.0 & 28.1 & 29.5 & 27.9 \\
\hline Line-4 & 30.4 & 27.1 & 32.6 & 33.5 \\
\hline Line-5 & 27.6 & 24.0 & 29.6 & 27.5 \\
\hline $\operatorname{LSD}_{0.05}(\mathrm{G})$ & 1.26 & 2.72 & 0.96 & 1.85 \\
\hline $\mathrm{LSD}_{0.05}(\mathrm{G} \times \mathrm{L})$ & & - & & - \\
\hline $\operatorname{LSD}_{0.05}(\mathrm{G} \times \mathrm{L} \times \mathrm{Y})$ & & & 2.122 & \\
\hline
\end{tabular}

Table 10: Tolerance indices of 20 barley genotypes under stress and non-stress conditions.

\begin{tabular}{lcccccccccc}
\hline Genotypes & YP & YS & TOL & MP & YR & DSI & GMP & STI & YSI & YI \\
\hline G123 & 5.91 & 4.39 & 1.52 & 5.15 & 0.26 & 1.03 & 5.09 & 0.45 & 0.74 & 1.22 \\
\hline G132 & 5.74 & 3.98 & 1.75 & 4.86 & 0.31 & 1.23 & 4.78 & 0.43 & 0.69 & 1.11 \\
\hline Line-1 & 5.48 & 4.44 & 1.04 & 4.96 & 0.19 & 0.77 & 4.93 & 0.43 & 0.81 & 1.24 \\
\hline Line-2 & 6.11 & 4.57 & 1.54 & 5.34 & 0.25 & 1.02 & 5.28 & 0.47 & 0.75 & 1.27 \\
\hline Line-3 & 5.83 & 4.19 & 1.65 & 5.01 & 0.28 & 1.14 & 4.94 & 0.44 & 0.72 & 1.17 \\
\hline Line-4 & 6.39 & 4.67 & 1.72 & 5.53 & 0.27 & 1.09 & 5.46 & 0.48 & 0.73 & 1.3 \\
\hline Line-5 & 5.41 & 3.83 & 1.58 & 4.62 & 0.29 & 1.18 & 4.55 & 0.4 & 0.71 & 1.07 \\
\hline
\end{tabular}

GYP: Yield under non-stress condition (t. ha ${ }^{-1}$ ), GYS: Yield under stress condition (t. ha ${ }^{-1}$ ), Tol: Tolerance index, Mp: Mean productivity, Yr: Yield reduction ratio, DSI: stress susceptibility index, GMP: Geometric mean productivity, STI: Stress tolerance index, YSI: Yield stability index, YI: Yield index.

The higher value of STI indicates higher tolerance and yield potential for the genotype. These results indicated that the genotypes with high STI usually have a high difference in yield in the two different conditions. In general, similar ranks for the genotypes were observed by GMP and MP indices as well as STI, which suggested that these three indices were equal for selecting genotypes.

A similar indication was obtained by Zare (2012) who reported that MP, STI, and GMP were the best criteria for selection of high yielding genotypes under stress and non-stress conditions in barley. And by Abdi et al. (2012) who showed that various drought resistance indexes indicated that three indexes; those of Mean Productivity (MP), Geometrical Mean (GMP) and Stress Tolerance Index (STI) were the most important indexes for the identification of a genotype's resistance to drought in wheat.

The values of YSI were 0.81 for Line1 in both seasons. This agrees with the conclusion of Mohammadi et al. (2010) who reported that YSI to be a more useful index to discriminate droughtresistant from drought-susceptible genotypes. Therefore, breeders should select this index for selection of stress-tolerant genotypes.
Regarding YI, the values were 1.30 for Line4 and 1.27 for Line2. YI can be used as a selection criterion, although it only ranks cultivars based on yield stress (Ys).

On the other hand, one genotype gave the lowest reduction in the yield (TOL) compared with the rest genotypes. Also, data in tables (10) indicated that this genotype possessed low values for YR and DSI less than one, Line1 (0.19 and 0.77)

Genotypes with low DSI values less than one can be considered as the salinity tolerant genotypes. Because the small DSI values of these genotypes indicated that the percentage reduction in grain yield due to stress compared with grain yield under favorable conditions (yield potential) was low. Our results show that these genotypes were more tolerant to salinity

Among the stress tolerance indicators, larger values of TOL and DSI represent relatively more sensitive to stress, thus smaller values of TOL and DSI are favored. Selection based on both two indices favors genotypes with low yield under nonstress conditions and high yield under stress conditions, these indications were concluded by Golabadi et al. (2006), Nazari and Pakniat. (2010) and Ahmadizadeh et al. (2012). 
Table 11: Simple correlation coefficients between grain yield under normal Yp, grain yield under stressed Ys conditions and tolerance indices overall the two growing seasons.

\begin{tabular}{|c|c|c|c|c|c|c|c|c|c|c|}
\hline & YP & YS & TOL & MP & YR & DSI & GMP & STI & YSI & YI \\
\hline YP & 1 & $0.736^{*}$ & 0.486 & $0.939 * *$ & 0.126 & 0.124 & $0.919 * *$ & $0.951 * *$ & -0.126 & $0.726^{*}$ \\
\hline YS & & 1.000 & -0.234 & $0.924 * *$ & -0.578 & -0.580 & $0.943 * *$ & $0.892 * *$ & 0.578 & $1.000 * *$ \\
\hline TOL & & & 1.000 & 0.156 & $0.926 * *$ & $0.927 * *$ & 0.104 & 0.214 & $-0.926^{* *}$ & -0.247 \\
\hline MP & & & & 1.000 & -0.223 & -0.225 & $0.999 * *$ & $0.991 * *$ & 0.223 & $0.919 * *$ \\
\hline YR & & & & & 1.000 & $0.996^{* *}$ & -0.274 & -0.160 & $-1.000 * *$ & -0.589 \\
\hline DSI & & & & & & 1.000 & -0.276 & -0.165 & $-0.996 * *$ & -0.591 \\
\hline GMP & & & & & & & 1.000 & $0.986 * *$ & 0.274 & $0.938 * *$ \\
\hline STI & & & & & & & & 1.000 & 0.160 & $0.885 * *$ \\
\hline YSI & & & & & & & & & 1.000 & 0.589 \\
\hline YI & & & & & & & & & & 1.000 \\
\hline
\end{tabular}

Correlation analysis between stress indices and yield components showed that grain yield under irrigated and stress condition was positively correlated with MP, STI, GMP and YI, (Table 11). While, yield under stress condition was positively correlated with YSI, and negatively correlated with $\mathrm{Yr}$ and DSI .Furthermore, correlation analysis between the various stress-tolerant indices used in this study provides interesting observations. MP, YSI, STI, GMP, and YI showed positively significantly correlated with each other, as well as showed a significant negative correlation with YSI. These results are in general agreement with those reported by Nazari and Pakniyat (2010), Abdi et al. (2012) and Muhammad et al. (2012).

Results of shoot length, root length, seedling dry weight $(\mathrm{g}), \mathrm{K}^{+}$content and $\mathrm{N}^{+}$a content Table (15). Significant differences were observed between salinity levels, whereas level $\left(10 \mathrm{dSm}^{-1}\right)$ was lowest harmful in connection with of shoot length, root length, seedling dry weight $(\mathrm{g}), \mathrm{K}^{+}$content and $\mathrm{N}^{+} \mathrm{a}$ content which was 9.69, 6.89, 0.14, 17.66 and 20.73, respectively. Compared with other salinity levels. On the other hand, the highest harmful of parameters in Table (15) was obtained by Salinity level $\left(16 \mathrm{dSm}^{-1}\right)$.

The negative effect of salinity stress is attributed to the fact that salt stress reduced the $\mathrm{K}^{+}$uptake and increased $\mathrm{Na}^{+}$uptake(Farooq et al., 2015) and causes ionic toxicity by replacing $\mathrm{K}^{+}$by $\mathrm{Na}^{+}$in cellular reactions (Shabala et al., 2006). Salinity affected germination in two ways, first; enough salt in the medium which decreased the osmotic potential to such a point which retarded or prevented the uptake of water necessary for mobilization of nutrients required for germination, second that salt constituents or ions may be toxic to the embryo (Rahman et al., 2008).

The results in Table (16) revealed that shoot length, root length, seedlings dry weight was significantly affected by cultivars. The results showed that line 4 had the tallest shoot length, root length, and seedlings dry weight which were 13.24 $\mathrm{cm}, 8.91 \mathrm{~cm}$ and $0.25 \mathrm{~g}$, respectively. However, Giza 132 cultivar had the shortest shoot length, root length and seedlings dry weight, which were $4.81 \mathrm{~cm}, 4.90 \mathrm{~cm}$ and $0.05 \mathrm{~g}$, respectively. The tested cultivars could be arranged according to shoot length, root length that and seedlings dry from the tallest to the shortest as follows lines 4, 2,1,3, Giza123, line 5 And Giza 132. The differences in Characters values could be attributed to the differences in genetic constitution of these cultivars.

The highest values for $\mathrm{K}^{+}$content shown in table (16) were obtained by line 2 . While the lowest $\mathrm{K}^{+}$ were obtained by the Giza 123. On the other hand, Giza132 cultivar gave the highest $\mathrm{Na}^{+}$content, which was $32.72 \mathrm{mg} \mathrm{g}^{-1}$ D.W.

Seedling, shoot length, root length characteristics and chemical constituents were significantly affected by the interaction between salinity levels and genotypes as shown in Tables (17). The lowest values of seedling characters and $\mathrm{K}^{+}$content were obtained by dry seed with a salinity level of $16 \mathrm{~d} \mathrm{Sm}^{-1}$ for genotype Giza 132(7.07). While the highest values, seedling characters and $\mathrm{K}^{+}$ content were obtained by Line4 (17.60) under the same level.

Table 12: Mean comparison of Germination rate and salinity level in the different barley genotypes.

\begin{tabular}{lccccc}
\hline Salinity level & $\begin{array}{c}\text { shoot } \\
\text { length }(\mathbf{c m})\end{array}$ & $\begin{array}{c}\text { shoot } \\
\text { length }(\mathbf{c m})\end{array}$ & $\begin{array}{c}\text { seedling dry } \\
\text { weight }(\mathbf{g})\end{array}$ & $\begin{array}{c}\text { K+ content } \\
\text { (mg g } \mathbf{- 1} \mathbf{D} . W\end{array}$ & $\begin{array}{c}\text { Na + content } \\
\text { (mg g }\end{array}$ \\
\hline 0 & 14.40 & 12.32 & 0.17 & 25.73 & 12.82 \\
\hline $10 \mathrm{dSm}-1$ & 9.69 & 6.89 & 0.14 & 17.66 & 20.73 \\
\hline $12 \mathrm{dSm}-1$ & 7.78 & 5.06 & 0.09 & 17.69 & 27.37 \\
\hline $14 \mathrm{dSm}-1$ & 5.89 & 3.82 & 0.06 & 15.24 & 34.40 \\
\hline $16 \mathrm{dSm}-1$ & 4.90 & 3.42 & 0.06 & 12.52 & 41.64 \\
\hline LSD & 0.94 & 0.71 & 0.03 & 3.04 & 3.67 \\
\hline
\end{tabular}


Table 13: Mean comparison of Germination rate and Genotypes in the different barley

\begin{tabular}{lccccc}
\hline Genotypes & $\begin{array}{c}\text { shoot } \\
\text { length(cm) }\end{array}$ & $\begin{array}{c}\text { shoot } \\
\text { length }(\mathbf{c m})\end{array}$ & $\begin{array}{c}\text { seedling dry } \\
\text { weight }(\mathbf{g})\end{array}$ & $\begin{array}{c}\text { K+ content } \\
\text { (mg/g D.W }\end{array}$ & $\begin{array}{c}\text { Na + content } \\
(\mathbf{m g} / \mathbf{g} \mathbf{D} . \mathbf{W}\end{array}$ \\
\hline 123 & 7.21 & 5.22 & 0.06 & 12.41 & 29.08 \\
\hline 132 & 4.81 & 4.90 & 0.05 & 15.43 & 32.72 \\
\hline Line 1 & 7.21 & 5.49 & 0.07 & 19.53 & 26.70 \\
\hline Line 2 & 12.88 & 8.54 & 0.16 & 21.67 & 22.05 \\
\hline Line 3 & 7.32 & 5.70 & 0.08 & 18.57 & 26.38 \\
\hline Line 4 & 13.24 & 8.91 & 0.25 & 21.17 & 22.95 \\
\hline Line 5 & 7.06 & 5.37 & 0.07 & 15.60 & 31.86 \\
\hline LSD & 1.03 & 0.60 & 0.03 & 2.41 & 2.76 \\
\hline
\end{tabular}

Table 14: Interactions effect between salinity levels and genotypes on seed germination, seedling, characteristics and chemical constituents of barley

\begin{tabular}{|c|c|c|c|c|c|c|}
\hline 递 & 部 & 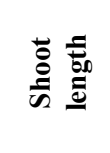 & ث) & 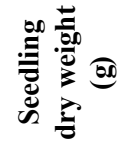 & 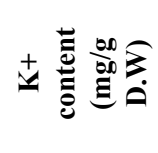 & 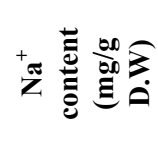 \\
\hline \multirow{5}{*}{123} & control & 13.77 & 12.2 & 0.084 & 18.53 & 14.17 \\
\hline & $10 \mathrm{dS} / \mathrm{m}$ & 9.50 & 6.1333 & 0.077 & 16.00 & 18.43 \\
\hline & $12 \mathrm{dS} / \mathrm{m}$ & 5.07 & 3.466 & 0.056 & 11.43 & 31.30 \\
\hline & $14 \mathrm{dS} / \mathrm{m}$ & 3.88 & 2.35 & 0.058 & 8.50 & 35.73 \\
\hline & $16 \mathrm{dS} / \mathrm{m}$ & 3.84 & 1.9333 & 0.037 & 7.57 & 45.77 \\
\hline \multirow{5}{*}{132} & control & 12.27 & 11.74 & 0.093 & 22.27 & 14.37 \\
\hline & $10 \mathrm{dS} / \mathrm{m}$ & 3.93 & 0.090 & 0.090 & 26.33 & 26.33 \\
\hline & $12 \mathrm{dS} / \mathrm{m}$ & 3.05 & 3.4833 & 0.040 & 14.33 & 32.97 \\
\hline & $14 \mathrm{dS} / \mathrm{m}$ & 2.89 & 2.66 & 0.004 & 11.30 & 38.63 \\
\hline & $16 \mathrm{dS} / \mathrm{m}$ & 1.93 & 1.8666 & 0.013 & 7.07 & 51.30 \\
\hline \multirow{5}{*}{ Line 1} & control & 14.35 & 12.35 & 0.085 & 25.40 & 12.93 \\
\hline & $10 \mathrm{dS} / \mathrm{m}$ & 8.25 & 0.073 & 0.073 & 22.17 & 17.57 \\
\hline & $12 \mathrm{dS} / \mathrm{m}$ & 6.13 & 4.266 & 0.078 & 20.07 & 27.77 \\
\hline & $14 \mathrm{dS} / \mathrm{m}$ & 4.32 & 2.4333 & 0.049 & 17.70 & 35.63 \\
\hline & $16 \mathrm{dS} / \mathrm{m}$ & 3.00 & 2.27 & 0.061 & 16.90 & 39.60 \\
\hline \multirow{5}{*}{ Line 2} & control & 16.97 & 12.343 & 0.379 & 34.53 & 10.53 \\
\hline & $10 \mathrm{dS} / \mathrm{m}$ & 14.32 & 9.3333 & 0.466 & 25.87 & 17.30 \\
\hline & $12 \mathrm{dS} / \mathrm{m}$ & 11.57 & 7.836 & 0.187 & 22.03 & 22.10 \\
\hline & $14 \mathrm{dS} / \mathrm{m}$ & 11.33 & 7.0333 & 0.102 & 21.03 & 28.70 \\
\hline & $16 \mathrm{dS} / \mathrm{m}$ & 10.20 & 6.133 & 0.107 & 16.90 & 31.63 \\
\hline \multirow{5}{*}{ Line 3} & control & 13.90 & 12.4 & 0.091 & 24.63 & 12.77 \\
\hline & $10 \mathrm{dS} / \mathrm{m}$ & 7.97 & 6.733 & 0.127 & 19.93 & 21.30 \\
\hline & $12 \mathrm{dS} / \mathrm{m}$ & 7.50 & 4.05 & 0.071 & 18.03 & 26.10 \\
\hline & $14 \mathrm{dS} / \mathrm{m}$ & 4.90 & 2.9166 & 0.056 & 16.63 & 31.33 \\
\hline & $16 \mathrm{dS} / \mathrm{m}$ & 2.33 & 2.383 & 0.072 & 13.63 & 40.40 \\
\hline \multirow{5}{*}{ Line 4} & control & 15.58 & 13.433 & 0.392 & 32.27 & 10.90 \\
\hline & $10 \mathrm{dS} / \mathrm{m}$ & 15.30 & 8.5666 & 0.099 & 29.30 & 14.30 \\
\hline & $12 \mathrm{dS} / \mathrm{m}$ & 14.77 & 8.266 & 0.094 & 21.53 & 21.90 \\
\hline & $14 \mathrm{dS} / \mathrm{m}$ & 10.70 & 7.033 & 0.115 & 20.13 & 27.90 \\
\hline & $16 \mathrm{dS} / \mathrm{m}$ & 9.83 & 7.25 & 0.101 & 17.60 & 31.77 \\
\hline \multirow{5}{*}{ Line 5} & control & 14.00 & 11.75 & 0.097 & 22.50 & 14.07 \\
\hline & $10 \mathrm{dS} / \mathrm{m}$ & 8.53 & 6.566 & 0.073 & 19.77 & 21.87 \\
\hline & $12 \mathrm{dS} / \mathrm{m}$ & 6.40 & 4.066 & 0.085 & 16.37 & 29.47 \\
\hline & $14 \mathrm{dS} / \mathrm{m}$ & 3.22 & 2.333 & 0.064 & 11.35 & 42.88 \\
\hline & $16 \mathrm{dS} / \mathrm{m}$ & 3.14 & 2.1333 & 0.039 & 8.00 & 51.00 \\
\hline LSD at $5 \%$ & & 2.30 & 1.35 & 0.064 & 5.3995 & 6.17 \\
\hline
\end{tabular}




\section{REFERENCES}

Abd El-Wahab, S. A. (2002). Wheat response to Ascorbic Acid under different soil water stress. J. Agric. Mansoura Univ., 27 (6): 4205-4219.

Abdi H.; E. Azizov ; M.R. Bihamta; R. Chogan and K. N. Aghdam (2012). Assessment and determination of the most suitable drought resistance index for figures and advanced lines of bread wheat. International Journal of Agri. Science (1): 78 -87.

Ahmadizadeh, M; Valizadeh, M; Shahbazi H and Nori, A. (2012). Behavior of durum wheat genotypes under normal irrigation and drought stress conditions in the greenhouse Afr. J. Biotechnol. 11(8): 1912-1923.

Ashraf, A. Abd El-Mohsen, M. A Abd El-Shafi., E. M. S Gheith and H.S Suleiman. (2015). Using different statistical procedures for evaluation drought tolerance indices of bread wheat genotypes. Adv. Agric. Biol. 4(1):19-30.

Ashraf M.Y., M.A Khan and S.A Ahsan (1990). Effect of salinit $(\mathrm{NaCl})$ and polyethyleneglycol (PEG) on germination, seedling growth and water uptake of sorghum. Pak. J. Agric. 6:33-36.

Bagheri, A. and H. HS. Abad (2007). Effect of drought and salt stresses on yield, yield components, and ion content of hull-less barley (Hordeum sativum L.). J. of new Agric. Sci., 3 (7): 1-15.

Bouslama, M. and W.T. Schapaugh (1984). Stress tolerance in soybean. Part 1: evaluation of three screening techniques for heat and drought tolerance. Crop Sci., (24): 933-937.

Bayoumi, T. Y. (2004). Diallel cross analysis for bread wheat under stress and normal irrigation treatments. Zagazig J. Agric. Res., 31 (2): 435-455.

El Goumi Y., M. Fakiri, O. Lamsaouri, M. Benchekroun (2014). Salt stress effect on seed germination and some physiological traits in three Moroccan barley (Hordeum vulgare, L.) cultivars. J. Mater. Environ. Sci. 5(2) :625-632.

Farhat, W.Z.E. (2005). Genetical studies on drought tolerance in bread wheat (Triticum aestivum L). M.sc. Thesis, Tanta Univ., Egypt.

Farooq, M.; M. Hussain,; A.Wakeel, and K.H.M. Siddique (2015). Salt stress in maize: effects, resistance mechanisms and management. A review. Agron.Sustain. Dev. 35: 461-481. doi: 10.1007/s13593-015-0287-0.

Fernandez, G.C.J. (1992). Effective selection criteria for assessing plant stress tolerance. In: Proceedings of on the Symposium Taiwan, August, (25): 257-270.
Fischer, R.A. and R. Maurer, (1978). Drought resistance in spring wheat cultivars. I. Grain yield response. Aust. J. Agric. Res., 29: 897-907 .

Gavuzzi, P.; F. Rizza; M. Palumbo; R.G. Campaline; G.L. Ricciardi and B. Borghi (1997). Evaluation of field and laboratory predictors of drought and heat tolerance in winter cereals. Can. J. Plant Sci., (77): 523531.

Golabadi, M; A. Arzani, and S. A. M. Mirmohammadi Maibody.(2006). Assessment of drought tolerance in segregating populations in durum wheat. Afr. Agric. J. Res., 1: 162-171

Golestani, S. A. and M. T. Assad (1998). Evaluation of four screening techniques for drought resistance and their relationship to yield reduction ratio in wheat. Euphytica, (103): 293-299.

Gomez K.M, A. A. Gomez (1984) .Statistical Procedures for Agricultural Research. $2^{\text {nd }}$ ed.John Wily and Sons, New York, p. 68.

Hossain, A.B.S.; A.G. Sears; T.S. Cox and G.M. Paulsen (1990). Desiccation tolerance and its relationship to assimilate partitioning in winter wheat. Crop Sci, (30): 622-627.

Jackson, M. L. (1973). Soil Chemical Analysis. Prentice Hall of India Pvt. Ltd., New Delhi.

Katerji N., J.W. van Hoorn, A. Hamdy, M. Mastrorilli,

(2006) Classification and salt tolerance analysis of barley varieties. Agricultural Water Management, 85:84-92.

Krishnasamy, V. and D.V. Seshu (1990). Phosphine fumigation influence on rice seed germination and vigor. Crop Sci., 30: 28-85.

Mahmoud, Badeaa. A. M. (2006). Genetic evaluation of some barley traits in crosses under saline and non-saline conditions. M. Sc. Thesis Fac., Agric., Kafr El-Sheikh, Tanta Univ., Egypt.

Mohamed, M. E. A. (2004). Genetical analysis and evaluation of drought tolerance trait under different conditions in wheat (Triticum aestivum L). Ph.D. thesis, Tanta Univ., Egypt.

Mohammadi, A.A; G. Saeidi, and A. Arzani, (2010). Genetic analysis of some agronomic traits in flax (Linum usitatissimum L.). Aust J Crop Sci 4(5): 343-352.

Muhammad, I. K.; J. A. T. Da Silva and S. Huub (2012). Evaluation of barley genotypes for yielding ability and drought tolerance under irrigated and water-stressed conditions. American-Eurasian J. Agric. \& Environ. Sci., (3): 287-292. 
Nabipour, A. R.; S. B. Yazdi; A.A. Zali and K. Poustini (2002). Effects of morphological traits and their relations to stress susceptibility index in several wheat genotypes. BIABAN. 7: 31-47.

Nasser Sh., A. Nisar and M. Ashraf (2001). Effect of salt stress on germination and seedling growth of barley (Hordeum vulgare, L.), Pak. J. Biol. Sci., 4(3):359-360.

Nazari, L. and H. Pakniyat (2010). Assessment of drought tolerance in barley genotypes. Journal of Applied Sciences (2): 151-156.

Rana M., S. Husain, Rita A. Rivelli, R.A. James, (2002)

Avenues for increasing salt tolerance of crops, and the role of physiologically based selection traits. Plant soil. 247:93-105.

Rahman, M.; A. Soomro; M. Z. Ul-Haq and S. Gul (2008). Effects of $\mathrm{NaCl}$ salinity on wheat (Triticum aestivum L.) cultivars. World Journal of Agricultural Sciences, 4 (3): 398403.
Samarah, N. H.; A. M. Alqudah; J. A. Amayreh and G. M. McAndrews (2009). The Effect of late-terminal drought stress on yield components of four barley cultivars. J. Agron. Crop Sci.,195 (6): 427- 441.

Shabala, S.; V. Demidchik; L. Shabala; T.A.Cuin; S.J.Smith; A.J. Miller; J.M. Davies and I.A. Newman (2006). Extracellular $\mathrm{Ca}^{2+}$ Ameliorates $\mathrm{Na}$ Clinduced $\mathrm{K}+$ Loss from Arabidopsis root and leaf cells by controlling plasma membrane $\mathrm{K}+-$ permeable channels. Plant Physiol. 141: 1653- 1665.

Taghipour F., M. Salehi (2008). The study of salt tolerance of Iranian Barley (Hordeum vulgare, L.) genotypes in seedling growth stages, American-Eurasian J. Agric. \& Environ. Sci., 4 (5):525-529.

Vaezi, B.; V. Bavei and B. Shiran (2010). Screening of barley genotypes for drought tolerance by agro-physiological traits in field condition. African J. Agric. Res., 5 (9): 881-892.

Zare, M. (2012): Evaluation of drought tolerance indices for the selection of Iranian barley (Hordeum vulgare) cultivars. African Journal of Biotechnology Vol. 11(93), pp. 15975-15981. 


\section{الملخص العربى}

\section{ثقدير درجة تحمل إجهاد الملوحة في بعض التراكيب الوراثية من الثعير

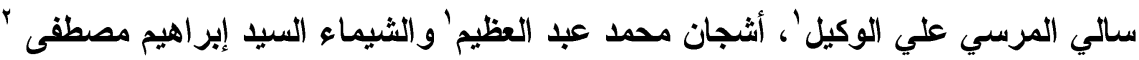 \\ "قشم بحوث الشعير \\ كوحدة تكنولوجيا البذور بالمنصورة \\ معهد بحوث المحاصيل الحقلية - مركز البحوث الزر اعية، بالمنصورة - مصر .}

تم تقييم سبع تر اكيب وراثية من الثعيرفي بيئتين مختلفتين،الاولي تحت الظروف الطبيعية في محطة بحوث

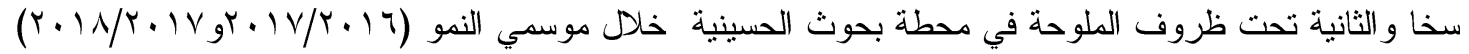
وتم إجر اء التجربة المعملية بقسم تكنولوجيا البذور بالمنصورة التابعين لمركز البحوث الزر اعية. وذلك لدر اسة مدي

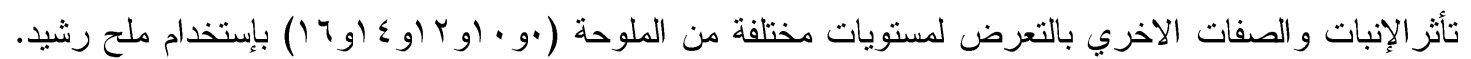

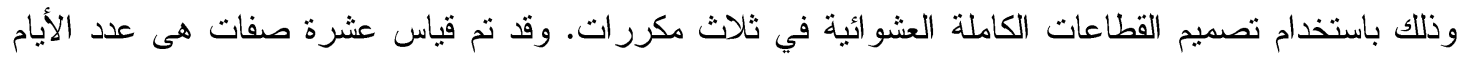

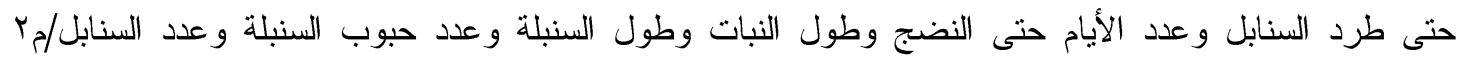

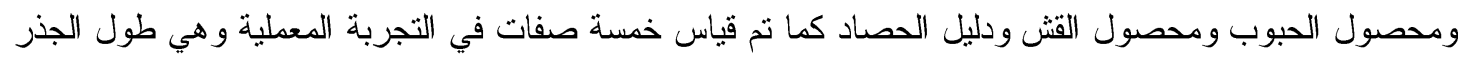
وطول المجموع الخضري و الوزن الجاف للبادرات ومحتوي البوتاسيوم ومحتوي الصوديوم. وكذلك تم تقدير ثمانية دلائل لتحمل الإجهاد. (TOL, MP, STI, GMP, Yr, DSI, YSI, YI) وقد اظهر تحليل التباين وجود إختلافات معنوية وعالية المعنوية لكل من المواسم والمواقع و التر اكيب الور اثثية و التفاعل بينهم لكل الصفات المدروسة. وكان هناك فروقا معنوية بين كل دلائل التحمل بين كل التز اكيب الور اثية المستخدمة.وقد كانت التزراكيب الوراثية سلالة ع، سلالةب وسلالة الهي الافضل في كلا الموقعين وكلا الموسمين بالنسبة لمحصول الحبوب، وكذلك بالنسبة لدلائل تحمل الملوحة كانت هذة التر اكيب هي الافضل حيث سجلت اعلي GMP, STI, YSI and YI القيم لكل من

وقد وجدت إختلافات معنوية بين مستويات الملوحة في المعمل حيث كان المستوي • 1 هو اقل المستويات تأثثراً مقارنة بالمستويات الاخري، بينما كان المستوي 17 هو اعلي المستويات تأثنير أ. 